\title{
Pore Size and Bulk Density as Mechanical Soil Factors Impeding Root Development ${ }^{1}$
}

\section{A. Lugo-López ${ }^{2}$ \\ INTRODUCTION}

Mechanical impedance can be a factor of considerable importance because of its direct and indirect influences on plant growth (5) ${ }^{3}$. Compact soils and subsoils can offer marked resistance to root development. Soil science recognizes genetically developed compacted layers as well as trafficinduced pans ( 8 ). No really adequate, direct methods have been developed for measuring the work done by roots in penetrating compact soil layers. Thus, measurements of soil properties that might influence root development are generally used. Among them, bulk density and pore size are rather useful yardsticks. This paper reports data on bulk density and pore size for selected profiles where three major uncultivated pasture grasses-Para, Guinea, and Bermuda-were growing. The data are complemented with observations on root development in an attempt to relate the influence of the indicated soil factors on the rooting depth of the grasses.

\section{MATERIALS AND METHODS}

The observations and measurements herein reported were done in connection with an extensive study of the major soils of the Lajas Valley in southwestern Puerto Rico (4). Data from seven profiles are reported here including the Aguirre, Guánica, Fraternidad, Fe, and Jácana soils. The soils are generally deep, with a strikingly high, almost uniform clay content of the expanding-lattice type, very slow hydraulic conductivity in the subsoil $(3)$, and very low aggregate stability below the surface layer (2). They are relatively low in organic matter and nitrogen, and generally high in soluble salts and exchangeable sodium, both of which increase with depth. Observations on root development of Para grass, Guinea grass, and Bermuda grass were made in pits 4 feet wide, 4 feet long, and 6 feet deep.

Four undisturbed soil cores were taken from each of the well-defined visible horizons with an Uhland sampler 3 inches in diameter by 3 inches in length. The cores were dried in an oven at $110^{\circ} \mathrm{C}$. As the sampler used had a known volume, bulk density was calculated by dividing the net dry weight of the soil by its original volume. The water retained at $\mathrm{pF} 1.78$,

1 Contribution from the Gurabo Substation.

2 Soil Scientist in Charge of the Gurabo Substation, Agricultural Experiment Station, University of Puerto Rico, Gurabo, P. R.

${ }^{3}$ Italic numbers in parentheses refer to Literature Cited, p. 44. 
considered here as an index of the nature of the soil porosity, was measured by bringing the soil cores to equilibrium with a $60-\mathrm{cm}$. tension and determining the variation in weight of the core.

\section{RESULTS}

Measurements of bulk density and porosity are given in table 1 for the selected soils studied where three different uncultivated grasses were growing. Observations on root development are also recorded in table 1.

In an Aguirre soil, profile 2, Para grass roots were abundant in the fluffy, light, topmost 3 inches and then decreased with increases in depth which correlated with increasing percentage by volume of small pores even though bulk-density values were rather low. In profile 19 , there was a sharp reduction in root development below the upper 9-inch layer. In this core both high soil density and microporosity are probably at play.

Guinea grass roots developed normally in profile 18, a Fraternidad soil, at densities ranging from 1.15 to $1.39 \mathrm{gm}$./cc. with over 60 percent of small pores. This grass is rather deep-rooted, prevails in drier areas under natural conditions, and tolerates drouth normally well. In the Jácana soils (profiles 8 and 9) a similar situation was observed with roots extending all the way down to the weathered, somewhat compact parent rock material.

The development of roots of Bermuda grass was apparently limited in profile 17 by the denser layer below the upper two horizons. In profile 6 they went deeper, the soil was much lighter, and there were fewer small pores than in profile 17 .

\section{DISCUSSION}

The influence of these soil factors upon root development has been recognized by Veihmeyer and Hendrickson $(9,10)$ since 1946 . They reported critical density values for some loam soils of 1.7 to 1.8 , and of 1.6 to 1.7 for clays. In Aiken clay $1.46 \mathrm{gm}$./cc. was the limiting density. According to Lutz (5): "They attribute the failure of roots to penetrate soil above the critical apparent density to the size of the pores and not to the lack of oxygen; roots penetrated saturated noncompacted soils".

In 1956 Lugo-López and Acevedo reported on compaction studies of irrigated soils (1). They measured in foot-pounds the work required in sampling $3^{\prime \prime} \times 3$ " soil cores. Significant differences were obtained, the compacted soils requiring much more effort than the loose ones to sample. The same type of resistance values were also reported by Parker and Jenny (7) who found that they increased exponentially with increases in core weight. Lutz (5) stated: "The values give an indirect estimation of the relative amounts of work done by roots in penetrating tight soils".

Studies to improve genetically compact soils have been conducted locally 
TABLE 1.-Bulk density and volume of small pores of selected soils as related to rooting depth of Para, Guinea, and Bermuda grasses

\begin{tabular}{|c|c|c|c|c|c|c|}
\hline Vegetation & $\begin{array}{c}\text { Soil } \\
\text { series }\end{array}$ & $\begin{array}{c}\text { Soil } \\
\text { profile } \\
\text { identifi- } \\
\text { cation No. }\end{array}$ & Depth & $\underset{\text { Bulk }}{\text { density }}$ & $\begin{array}{c}\text { Volume of } \\
\text { pores with } \\
\text { water at } \\
\text { pF } 1.78\end{array}$ & Observations on root development \\
\hline & & & Inches | & {$[\mathrm{g} m . / \mathrm{cc}$} & Percent & \\
\hline $\begin{array}{l}\text { Para grass } \\
\text { (Panicum } \\
\text { purpuras- } \\
\text { cens) }\end{array}$ & Aguirre & 2 & $\mid \begin{array}{c}0-3 \\
3-12 \\
12-32 \\
38-47 \\
47-70\end{array}$ & $\begin{array}{l}0.88 \\
1.00 \\
1.17 \\
1.10 \\
1.08\end{array}$ & $\begin{array}{l}58.2 \\
60.0 \\
78.0 \\
73.6 \\
71.3\end{array}$ & $\begin{array}{l}\text { Abundant fibrous roots in } \\
\text { upper } 3 \text { inches, decreasing } \\
\text { down to } 36 \text { inches, with few } \\
\text { roots as far down as } 53 \\
\text { inches. }\end{array}$ \\
\hline Do. & do. & 19 & $\left|\begin{array}{c}0-9 \\
9-19 \\
19-28 \\
28-46 \\
46-66\end{array}\right|$ & $\begin{array}{l}1.22 \\
1.43 \\
1.40 \\
1.26 \\
1.26\end{array}$ & $\begin{array}{l}63.4 \\
68.0 \\
77.6 \\
84.8 \\
78.6\end{array}$ & $\begin{array}{l}\text { Abundant in upper } 9 \text { inches } \\
\text { with only a few roots ex- } \\
\text { tending through the } 2 \\
\text { layers below. }\end{array}$ \\
\hline $\begin{array}{l}\text { Guinea grass } \\
(P . \text { maxi- } \\
\text { mum })\end{array}$ & $\begin{array}{l}\text { Fra- } \\
\text { ter- } \\
\text { ni- } \\
\text { dad }\end{array}$ & 18 & $\left|\begin{array}{c}0-9 \\
9-21 \\
21-29 \\
29-40 \\
40-44 \\
44-70\end{array}\right|$ & $\begin{array}{l}1.15 \\
1.23 \\
1.39 \\
1.33 \\
1.35 \\
1.39\end{array}$ & $\begin{array}{l}60.3 \\
66.9 \\
72.3 \\
71.9 \\
67.5 \\
63.5\end{array}$ & $\begin{array}{l}\text { Very abundant in upper } 9 \\
\text { inches, abundant down to } \\
21 \text { inches, with a large } \\
\text { amount of fine roots ex- } \\
\text { tending to } 44 \text { inches but } \\
\text { following cracks and cleav- } \\
\text { age planes; some roots } \\
\text { penetrated easily to lower } \\
\text { depths. }\end{array}$ \\
\hline Do. & $\begin{array}{l}\text { Já- } \\
\text { cana } \\
\text { do. }\end{array}$ & 8 & $\left|\begin{array}{c}0-9 \\
9-23 \\
23-41 \\
41+ \\
0-10 \\
10-24 \\
24-29 \\
29-38 \\
38+\end{array}\right|$ & $\begin{array}{l}1.36 \\
1.33 \\
1.28 \\
1.64 \\
1.24 \\
1.13 \\
1.27 \\
1.46 \\
-\end{array}$ & $\begin{array}{l}64.0 \\
64.6 \\
64.1 \\
64.9 \\
64.8 \\
64.5 \\
65.8 \\
56.2 \\
-\end{array}$ & $\begin{array}{l}\text { Abundant in upper } 9 \text { inches, } \\
\text { but extending all the way } \\
\text { to the weathered parent } \\
\text { material at } 43 \text { inches. } \\
\text { Abundant in upper } 10 \text { inches } \\
\text { with some extending all the } \\
\text { way down to the weathered } \\
\text { rock material. }\end{array}$ \\
\hline $\begin{array}{l}\text { Bermuda } \\
\text { grass (Cy- } \\
\text { nodon } \\
\text { Dactylon) }\end{array}$ & $\mathrm{Fe}$ & 17 & $\left|\begin{array}{c}0-6 \\
6-14 \\
14-24 \\
24-33 \\
33-46 \\
46-64\end{array}\right|$ & \begin{tabular}{|l|}
1.36 \\
1.35 \\
1.46 \\
1.63 \\
1.60 \\
1.54
\end{tabular} & $\begin{array}{l}68.9 \\
70.6 \\
74.2 \\
74.8 \\
75.7 \\
74.7\end{array}$ & $\begin{array}{l}\text { Most roots confined to upper } \\
6 \text {-inch layer; some ex- } \\
\text { tended to } 14 \text { inches; only } \\
\text { very few down to } 6+\text { inches. }\end{array}$ \\
\hline Do. & $\begin{array}{c}\text { Guáni- } \\
\text { ca }\end{array}$ & 6 & $\mid \begin{array}{c}0-9 \\
9-18 \\
18-33 \\
33-45 \\
45-60 \\
60-72\end{array}$ & $\begin{array}{l}1.04 \\
1.02 \\
1.01 \\
1.07 \\
1.15 \\
1.14\end{array}$ & $\begin{array}{l}61.5 \\
59.9 \\
63.2 \\
65.2 \\
65.8 \\
67.6\end{array}$ & $\begin{array}{l}\text { Abundant down to } 45 \text { inches; } \\
\text { only a few as far as } 72 \\
\text { inches. }\end{array}$ \\
\hline
\end{tabular}


(6). The infiltration capacity of a tight soil was increased tenfold by ordinary plowing and harrowing only. Digging down around the borders of the wetted area disclosed that most of the water entering the soil of the plowed and harrowed plots through the immediate surface moved laterally after reaching the claypan. Where the claypan was shattered by the subsoil standard the water moved downward through the disturbed layer.

In general, root development in uncultivated pasture grasses of the types studied seems to respond to the combined variations in bulk density and pore size. Careful recognition must be given the specific genetic differences of the plants.

\section{SUMMARY}

Measurements of pore size and bulk density for seven clay soils are reported in this paper as related to observations on root development under field conditions of Para, Guinea, and Bermuda grasses. The combined effects of high bulk density and predominantly small pores apparently reduce root development in Para and Bermuda. Guinea grass, a dryland forage, is able to send roots through relatively dense soil horizons with high microporosity. This might explain, at least in part, the drought tolerance of this grass.

\section{RESUMEN}

Se informan aquí medidas de la porosidad y la densidad aparente de siete suelos arcillosos y se relacionan estos con observaciones en cuanto al desarrollo de raíces, bajo condiciones de campo, de malojillo, yerba de Guinea y yerba Bermuda. El efecto combinado de alta densidad y volumen mayor de poros pequeños aparentemente reduce el desarrollo de raíces del malojillo y la Bermuda. Las raíces de la yerba de Guinea, un forraje de zonas áridas, pueden penetrar a través de horizontes densos, donde predominan los poros pequeños. Esto puede explicar en parte la resistencia de esta yerba a condiciones de sequía.

\section{LITERATURE CITED}

1. Lugo-López, M. A., and Acevedo, G., Effects of tractor-traffic compaction on the physical properties of as irrigated soil in southwestern Puerto Rico, J. Agr. Univ. P. R. 40(4) 235-44, 1956.

2. Lugo-López, M. A., and Juárez, Jr., J., Evaluation of the effect of organic matter and other soil characteristics upon the aggregate stability of some tropical soils. J. Agr. Univ. P. R. 43(4) 268-72, 1959.

3. Lugo-López, M. A., and Pérez-Escolar, R., Hydraulic conductivity of subsoils of Lajas Valley, J. Agr. Univ. P. R. 43(t) 273-7, 1959.

4. Lugo-López, M. A., Pérez-Escolar, R., Acevedo, G., and Juárez, Jr., J., Nature and Properties of Major Soils of Lajas Valley, P. R., Agr. Exp. Sta. Bul. 149, 1959.

5. Lutz, J. F., Mechanical impedance and plant growth; chapt. 2 in Soil Physical 
Conditions and Plant Growth, B. T. Show, ed., Agronomy Monographs vol. II, Academic Press Inc., New York, N. Y., 44-53, 1952.

6. Martínez, M. B., and Lugo-López, M. A., Influence of subsoil shattering and fertilization on sugarcane production and soil infiltration capacity, Soil Sci. 75(4) 307-15, 1953.

7. Parker, E. R., and Jenny, H., Water infiltration and related soil properties as affected by cultivation and organic fertilization, Soil Sci. $60353-76,1945$.

8. Raney, W. A., Edminster, T. W., and Allaway, W. H., Current status of research in soil compaction, Soil. Sci. Soc. Amer. Proc. 19(4) 423-8, 1955.

9. Veihmeyer, F. J., and Hendrickson, A. H., Soil density as a factor in determining the permanent wilting percentage, Soil Sci. 62 451-6, 1946.

10. —., Soil density and root penetration, Soil Sci. 65 487-93, 1948. 